\title{
Alpha amylase and Alpha glucosidase inhibitory effects of aqueous stem extract of Salacia oblonga and its GC-MS analysis
}

\author{
Gladis Raja Malar Chelladurai ${ }^{1,3}$, Chellaram Chinnachamy ${ }^{2,3}$ * \\ ${ }^{1}$ Department of Chemistry, Sathyabama University, Chennai, Tamilnadu, India, ${ }^{2}$ Applied Biotechnology Department, \\ Sur College of Applied Sciences, Sultanate of Oman, ${ }^{3}$ Vel Tech Multitech Engg. College, Chennai, \\ Tamil Nadu, India
}

\begin{abstract}
Our present investigation deals with the phytochemical screening, estimation of total flavonoids, terpenoids and tannin contents to evaluate the anti-diabetic activities of Salacia oblonga stem followed by GC-MS analysis. It explores the natural compounds and the potential $\alpha$-amylase and $\alpha$-glucosidase inhibitory actions of stem extracts. The aqueous stem extract was selected from other extracts (ethanol, acetone, petroleum ether and chloroform) for the in vitro study of anti-diabetic activity by alpha amylase and alpha glucosidase inhibitory assays. The stem extract was also analyzed by gas chromatography mass spectrometry to identify the natural chemical components. Phytochemical analysis of aqueous stem extract showed major classes of secondary metabolites such as phenols, flavonoids, alkaloids, terpenoids, tannins, saponins. The total flavonoid, terpenoid, and tannin contents were quantified as $19.82 \pm 0.06$ $\mathrm{mg} \mathrm{QE} / \mathrm{g}, 96.2 \pm 0.20 \mathrm{mg} / \mathrm{g}$ and $11.25 \pm 0.03 \mathrm{mg} \mathrm{TAE} / \mathrm{g}$ respectively. The percentage inhibition of assays showed maximum inhibitory effects $(59.46 \pm 0.04 \%$ and $68.51 \pm 0.01 \%)$ at a concentration of $100 \mathrm{mg} /$ $\mathrm{mL}$. The $\mathrm{IC}_{50}$ values of stem extract was found to be $73.56 \mathrm{mg} / \mathrm{mL}$ and $80.90 \mathrm{mg} / \mathrm{mL}$ for alpha amylase and alpha glucosidase inhibition. Fifteen chemical constituents were found by GC-MS analysis. This study suggest the aqueous stem extract of Salacia oblonga might be considered as potential source of bio active constituents with excellent antidiabetic activity.
\end{abstract}

Keywords: Salacia oblonga. Antidiabetic. $\alpha$-Amylase. $\alpha$-Glucosidase. Terpenoids.

\section{INTRODUCTION}

Floral species were got an important place in the pharmaceutics, because of their therapeutic efficacy. This is due to the availability of potentially active natural chemical constituents. Natural products are secondary metabolites which are produced by plants through metabolic pathway. These phytochemical compounds have the capacity to cure fever, inflammation, cancer, cardiac disease, neurological disease, obesity, asthma, ulcer, urinary infections and viral disease (Sharma, Sharma, 2014). Diabetes mellitus $(\mathrm{DM})$ is one of the non-communicable life threatening diseases. These are non-infectious and non-transmissible. This is largely due to physical inactivity, unhealthy diets, obesity, raised blood cholesterol and glucose (Singh, Kumar, 2015). DM is a chronic disease, characterized

*Correspondence: C. Chellaram. Assistant Professor ' $\mathrm{C}$ '. Applied Biotechnology Department, College of Applied Sciences (Ministry of Higher Education), P.O.Box: 484, Zip code:484, Sur. Sultanate of Oman, GSM: +968 91419757. Phone: +968 25546802. Email: chellaramc.sur@cas.edu.om by metabolic disorder associated with high blood sugar (Pallavi et al., 2015). It occurs due to the pancreas does not produce enough insulin or when the body cannot use the insulin effectively (Arumugam, Manjula, Paari, 2013). It can be classified into four types (Type 1 diabetes mellitus, Type 2 diabetes mellitus, Gestational diabetes mellitus and Non-classical causes of DM) on the basis of the pathogenic process which leads to hyperglycemia (Powers, 2011). Type 1 diabetes mellitus is known as insulin dependent DM. It is a catabolic disorder caused by an auto immune reaction, resulting in selective beta cells destruction which produces severe insulin deficiency due to the inability of beta cells to respond any insulinogenic stimuli. Nowadays children or young adults are suffered very much. Type 2 diabetes mellitus is previously known as non-insulin dependent $\mathrm{DM}$, a heterogeneous group of disorders characterized by insulin resistance, where the cells in the body do not respond to insulin (Mamun-or-Rashid et al., 2014). Gestational diabetes occurs during pregnancy period. This is due to the resistance of insulin by placenta and placental 
hormones. Non classical causes of DM can be either genetic or acquired. DM is one of the main killers within the next 25 years. The number of people from worldwide multiplies with diabetes. Thus it is a global concern until the successive treatment is discovered. Nowadays many synthetic medicines are discovered, but they can produce many side effects (Ranjith, Rajasree, Sankar, 2012) Hence it is required for the search of herbal treatment with low cost and no side effects. Natural herbal medicines were investigated to control the glucose production or absorption.

Plants play vital role in the medicinal field, because of its healing capacity. Phytochemical screening is the major tool to bring about the wonderful potential of plants. Plant metabolites such as alkaloids, terpenoids, phenols, flavonoids, tannin, saponin were responsible for potential activities (Nittya, 2016). Flavonoids might be responsible for multi potential activities. The seasonal change of flavonoids may alter the anti-diabetic activity of herbal plants. Nowadays so many potentially active anti-diabetic herbal plants were identified by researchers (Stalin, Vivekanandan, Bhavya, 2013; Arumugam, Gunasekaran, Perumal, 2014). But, the growing population creates demand for herbal medicines. This is due to cheap and has no side effects. The present study was carried out to investigate the anti-diabetic herbal activity of aqueous stem extract of $S$. oblong $a$ and the identification of natural chemical constituents which were responsible for the bioactivity. Gas Chromatography Mass Spectroscopy is most commonly used method for the identification of new phytochemical compounds and for the quantification purpose. In this method the availability of unknown organic compounds can be found by matching the spectra with reference spectra.

Salacia oblonga (family: Clasteraceae) is a traditional herbal plant widely available in Srilanka, tropical regions of Africa and southern regions of India. It is a woody climber, commonly known as ekanayaka, saptrangi and ponkoranti. A wide variety of species of Salacia grow in India (Ramamoorthy et al., 2010). It is rich in antioxidants, secondary metabolites like alkaloids, terpenoids, flavonoids, steroids, tannins, saponins and phenolic compounds. It is reported that the root part is mainly used for the treatment madhumeha, the ancient name of diabetes. It is also used for curing rheumatism, skin disease, gonorrhea and fever. The nutrient content present in the $S$. oblonga can be used as a liver tonic. It has very good antimicrobial and anti-inflammatory activities (Ismail et al., 1997). The root extract was used as a source for the treatment of diabetes (Sujata, Mamta, Rachana, 2013). The natural chemical constituents of Salacia were used to prevent sugars in food from being absorbed by the body. It inhibits the breakdown of glucose and also prevents the deposition of extra fat in our body. Our present study reveals the qualitative and quantitative measurement of potential natural constituents and quantification flavonoids, terpenoids and tannins to investigate the efficacy of in vitro anti-diabetic activity of the aqueous stem extract of S. oblonga.

\section{MATERIAL AND METHODS}

\section{Chemicals}

Ethanol, acetone, ethanol, methanol, petroleum ether, chloroform, aluminium chloride, dinitrosalicylic acid, sodium potassium tartrate, $\alpha$-amylase, dimethyl sulfoxide, $p$-nitrophenyl- $\alpha$-glucopyranoside, $\alpha$-glucosidase, and other chemicals used for the analysis were received from HIMEDIA laboratory, Mumbai, India.

\section{Collection and identification of plant material}

The healthy plants of S.oblonga were collected from different regions of Western Ghats (India). The collected plants were authenticated by Dr.Vijaya Kumar, Associate professor, Department of Botany, S.T. Hindu College, Nagercoil, 629002. The stem was washed thoroughly by tap water to remove all impurities. Then it was cut and dried under shadow for four weeks. The dried stems were powdered by ball mills and maintained at Sathyabama University, Chennai-600 119, Tamil Nadu, India.

\section{Preparation of plant extract}

Extraction of the plant samples was done according to the method (Boulekbache-Makhlouf, Slimani, Madani, 2012). About $1 \mathrm{~g}$ of dried fine powder (humidity 6.6\%) of S. oblonga stem samples were extracted with $15 \mathrm{~mL}$ acetone, ethanol (75\%), chloroform, petroleum ether and water for 1 min using an Ultra Turrax mixer (T10 basic, $13,000 \mathrm{rpm}$ ) and soaked overnight at room temperature. The sample was then filtered through Whatman No.1 filter paper in a Buchner funnel. The filtered solution was evaporated under vacuum in a rotaevaporator at $40^{\circ} \mathrm{C}$ to a constant weight and then dissolved in respective solvents. The concentrated extracts were stored in airtight container in refrigerator below $10{ }^{\circ} \mathrm{C}$.

\section{Phytochemical screening of S.oblonga}

Screening of secondary metabolites of stem extracts of $S$. oblonga were determined by the standard method 
(Priya, Chellaram, 2014). Phytochemical screening was carried out on the stem extracts using different solvents (aqueous, ethanol, acetone, petroleum ether and chloroform) to identify the major natural chemical groups such as tannins, saponins, flavonoids, phenols, alkaloids, terpenoids, glycosides, cardiac glycosides, coumarins and steroids. General reactions revealed the presence or absence of these compounds in the tested stem extracts.

\section{Qualitative analysis of phytochemicals}

\section{Test for flavonoids}

About $0.5 \mathrm{~mL}$ of aqueous stem extract of S.oblonga was shaken with pet ether to remove the fatty materials. The defatted residue was dissolved in $20 \mathrm{~mL}$ of $80 \%$ ethanol and filtered. Then $3 \mathrm{~mL}$ of the filtrate was mixed with $4 \mathrm{~mL}$ of $1 \% \mathrm{KOH}$. A dark yellow colour was observed, which indicates the presence of flavonoids.

\section{Test for saponins}

About $0.5 \mathrm{~mL}$ of stem extract was dissolved in $2 \mathrm{~mL}$ of boiling water in a test tube, allowed to cool and shaken to mix thoroughly. Foam appeared indicating the presence of saponins.

\section{Test for alkaloids}

About $0.5 \mathrm{~mL}$ of stem extract was mixed with about $8 \mathrm{~mL}$ of $1 \% \mathrm{HCl}$, warmed and filtered. Then $2 \mathrm{~mL}$ of filtrate was treated separately with Mayer's reagent. Turbidity was observed to indicate the presence of alkaloids.

\section{Test for tannins}

About $0.5 \mathrm{~mL}$ of extract was boiled with $20 \mathrm{~mL}$ of distilled water in a test tube and then filtered. $0.1 \% \mathrm{FeCl}_{3}$ was added to the filtrate. Appearance of brownish green coloration showed the presence of tannins.

\section{Test for coumarins}

About $0.5 \mathrm{~mL}$ of aqueous stem extract was taken in a small test tube and covered with filter paper moistened with $1 \mathrm{~N} \mathrm{NaOH}$. The test tube was placed for few minutes in boiling water. Then the filter paper was removed and examined in UV light for yellow florescence to indicate the presence of coumarins.

\section{Test for anthocyanin and betacyanin}

To $2 \mathrm{~mL}$ of the stem extract, $1 \mathrm{~mL}$ of $2 \mathrm{~N}$ sodium hydroxide was added and heated for $5 \mathrm{~min}$ at $100{ }^{\circ} \mathrm{C}$. Formation of yellow colour indicates the presence of betacyanin.

\section{Test for glycosides}

About $2 \mathrm{~mL}$ of stem extract was mixed with $3 \mathrm{~mL}$ of chloroform and $10 \%$ ammonium solution was added. Formation of pink colour was not identified, which indicates the absence of glycosides.

\section{Test for cardiac glycosides}

To $0.5 \mathrm{~mL}$ of the stem extract, $2 \mathrm{~mL}$ of glacial acetic acid and few drops of $5 \%$ ferric chloride were added. This under layered with $1 \mathrm{~mL}$ of concentrated sulphuric acid. Formation of brown ring at interface indicates the presence of cardiac glycosides.

\section{Test for terpenoids}

To $0.5 \mathrm{~mL}$ of the stem extract, $2 \mathrm{~mL}$ of chloroform was added and concentrated Sulphuric acid was added carefully. Formation of red brown colour at the interface indicates the presence of terpenoids.

\section{Test for phenols}

To $1 \mathrm{~mL}$ of the stem extract, $2 \mathrm{~mL}$ of distilled water followed by few drops of $10 \%$ ferric chloride was added. Formation of blue colour indicates the presence of phenols.

\section{Test for quinones}

To $1 \mathrm{~mL}$ of the stem extract, $1 \mathrm{~mL}$ of concentrated sulphuric acid was added. Formation of red colour indicates the presence of quinones.

\section{Test for steriods}

To $0.5 \mathrm{~mL}$ of the stem extract, $2 \mathrm{~mL}$ of chloroform and $1 \mathrm{~mL}$ of sulphuric acid were added. Formation of reddish brown ring at interface indicates the presence of steroids.

\section{Estimation of total flavonoid contents}

Total flavonoid contents present in the aqueous stem extract was determined by the aluminum chloride colorimetric method (Mervat et al., 2009). About 0.5 $\mathrm{mL}$ of stem extract of $S$. oblonga at a concentration of 1 $\mathrm{mg} / \mathrm{mL}$ was taken and the volume made up to $3 \mathrm{~mL}$ with methanol. Then $0.1 \mathrm{~mL} 10 \% \mathrm{AlCl}_{3}, 0.1 \mathrm{~mL}$ of potassium acetate and $2.8 \mathrm{~mL}$ distilled water were added sequentially. The test solution was vigorously shaken. The solution was incubated for 30 minutes. Absorbance was recorded by using UV-Visible spectrophotometer UV-2450 (Shimadzu) at $415 \mathrm{~nm}$. A standard calibration plot was generated using known concentrations of quercetin. The concentrations of flavonoid in the test samples were calculated from the calibration plot and expressed as $\mathrm{mg} \mathrm{QE} / \mathrm{g}$ of sample. 


\section{Estimation of total tannin contents}

Tannin content present in the aqueous stem extract of S. oblonga was carried out by the standard method (Babu, Samundeeswari, Chitti Babu, 2015). One mL of aqueous stem extract was mixed with $0.5 \mathrm{~mL}$ of folin-ciocalteau's reagent, followed by the addition of $(20 \%)$ sodium carbonate $\left(\mathrm{Na}_{2} \mathrm{CO}_{3}\right)$ solution $(1 \mathrm{~mL})$ and distilled water $(8 \mathrm{~mL})$. The reaction mixture was allowed to stand for 30 min at room temperature. The supernatant was obtained by centrifugation using $6,000 \mathrm{rpm}$ and absorbance was recorded at $725 \mathrm{~nm}$ using UV-Visible Spectrophotometer. Different concentrations of standard tannic acid were prepared and the absorbance of various tannic acid concentrations was plotted for a standard graph. The tannin content was expressed as mg TAE/g of the sample.

\section{Estimation of total terpenoids}

Total terpenoid content in the aqueous stem extracts were measured by the method (Indumathi et al., 2014). About $1 \mathrm{~g}$ of $S$. oblonga stem powder was taken separately and soaked in $15 \mathrm{~mL}$ of alcohol for 24 hours. Then it was filtered and the filtrate was extracted with petroleum ether, the ether extract was treated as total terpenoid. Total terpenoids were measured by the following formula,

(Final weight of the sample - Initial weight of the sample)

Weight of the sample

\section{Alpha-amylase inhibitory assay}

The alpha-amylase inhibitory activities of the stem extract of S.oblonga were carried out according to the standard method (Nickavar, Yousefian, 2009). The starch solution $(0.5 \% \mathrm{w} / \mathrm{v})$ used as the substrate was prepared by boiling potato starch in distilled water for $15 \mathrm{~min}$. The enzyme solution was prepared by dissolving $1 \mathrm{mg}$ of porcine pancreatic alpha amylase in $20 \mathrm{mM}$ phosphate buffer (100 mL, pH 6.9). The sample solutions were prepared in DMSO (dimethyl sulfoxide) in different concentrations (10 to $100 \mathrm{mg} / \mathrm{mL}$ ). The DNS solution (20 $\mathrm{ml} 96 \mathrm{mM}$ 3,5-dinitrosalicylic acid, $12 \mathrm{~g}$ sodium potassium tartrate in $8 \mathrm{ml}$ of $2 \mathrm{M} \mathrm{NaOH}$ and $12 \mathrm{~mL}$ deionized water) was used as the colouring reagent of reaction. Three sets of experiments were conducted for test, blank and control. A mixture of $1 \mathrm{~mL}$ of each of the test and enzyme solutions, in a test tube was incubated at $25^{\circ} \mathrm{C}$ for $30 \mathrm{~min}$. Then, after taking out $1 \mathrm{~mL}$ from this mixture, $1 \mathrm{~mL}$ of the abovementioned starch solution was added and the mixture was incubated at $25^{\circ} \mathrm{C}$ for $3 \mathrm{~min}$. Finally, $1 \mathrm{~mL}$ of the DNS solution was added. The tube was then covered and heated in water bath at $85{ }^{\circ} \mathrm{C}$ for $15 \mathrm{~min}$. After cooling the tube, the reaction mixture was diluted with distilled water $(9$ $\mathrm{mL}$ ). It was mixed well and the absorbance was recorded at $540 \mathrm{~nm}$. In case of blank, the DNS solution was added prior to the addition of the starch solution, while rest of the method was same as for the test. For control, all procedure was again the same except that plant extract was replaced by $1 \mathrm{~mL}$ of DMSO. Acarbose, a well-known anti-diabetic medicine, was used as a positive control. The percentage inhibition was calculated by the formula:

$$
\% \text { Inhibition }=\left[\left(\mathrm{A}_{\mathrm{c}}-\mathrm{A}_{\mathrm{s}}\right) / \mathrm{A}_{\mathrm{c}}\right] \times 100
$$

$\mathrm{A}_{\mathrm{c}}$-absorbance for control; $\mathrm{A}_{\mathrm{s}-\mathrm{b}}$ absorbance for standard

\section{Alpha-glucosidase inhibitory assay}

The $\alpha$-glucosidase inhibition was determined by the following modified methods (Matsui et al., 1996; Bräunlich et al., 2013). The $\alpha$-glucosidase reaction mixture contained $2.9 \mathrm{mM}$ p-nitrophenyl$\alpha$-glucopyranoside ( $\mathrm{pNPG}$ ), varying concentrations $(10 \mathrm{mg} / \mathrm{mL}$ to $100 \mathrm{mg} / \mathrm{mL})$ of $S$. oblonga stem extract and $1.0 \mathrm{U} / \mathrm{mL} \alpha$-glucosidase in sodium phosphate buffer, $\mathrm{pH}$ 6.9. Control tubes contained only DMSO, enzyme and substrate, while in positive controls acarbose replaced the sample extract. Mixtures without enzyme, sample extract and acarbose served as blanks. The reaction mixtures were incubated at $25^{\circ} \mathrm{C}$ for $5 \mathrm{~min}$, after which the reaction was stopped by boiling for $2 \mathrm{~min}$. Absorbance of the resulting p-nitro phenol (pNP) was determined at $405 \mathrm{~nm}$ using spectrophotometer and was considered directly proportional to the activity of the enzyme. The $\mathrm{IC}_{50}$ values were determined from plots of percentage inhibition versus log inhibitor concentration and were calculated by non-linear regression analysis from the mean inhibitory values. Acarbose was used as the reference drug for alpha glucosidase inhibition assay. All the tests were performed by triplicates.

\section{Gas chromatography - mass spectrometry analysis}

The stem extract of $S$. oblonga were subjected to GC-MS analysis. This method is used for the identification of biologically active natural chemical constituents. It was carried out by using GC-MS-5975C Agilent system composed of an auto sampler and a gas chromatograph interfaced with a mass spectrometer (GC-MS) instrument. It was worked with the following 
conditions: column Elite-1 fused silica capillary column (300.25 mm ID×1EM df, composed of $100 \%$ dimethyl poly siloxane), operating in electron impact mode at 70 $\mathrm{eV}$. A constant flow of $1.51 \mathrm{~mL} / \mathrm{min}$ and an injection volume $1 \mu \mathrm{L}$ of helium $(99.999 \%)$ gas was used as carrier gas (split ratio 10:1). The temperature of injector and ion source were maintained at $240{ }^{\circ} \mathrm{C}$ and $200{ }^{\circ} \mathrm{C}$ respectively. The oven temperature was programmed from $70{ }^{\circ} \mathrm{C}$ (isothermal for $2 \mathrm{~min}$ ) with an increase of $10{ }^{\circ} \mathrm{C}$ per minute to $300{ }^{\circ} \mathrm{C}$ per minute, ending with a 9 minute isothermal at $300{ }^{\circ} \mathrm{C}$. Mass spectra were taken at $70 \mathrm{eV}$, with a scan range $40-1000 \mathrm{~m} / \mathrm{z}$. Solvent cut time was $5 \mathrm{~min}$; MS start time being $5 \mathrm{~min}$; MS end time being $35 \mathrm{~min}$; Ion source temperature set to $200^{\circ} \mathrm{C}$ and interface temperature being $240{ }^{\circ} \mathrm{C}$.

\section{Identification of chemical constituents}

The chemical compounds were identified by comparing the spectral data obtained on the Gas Chromatograph Mass Spectroscopy with the data base of National Institute Standard and Technology (NIST) having more than 62000 patterns. The name of the chemical component, molecular weight and the chemical structure of the stem extract of S.oblonga were identified.

\section{Statistical analysis}

Each result was repeated three times and represented by Mean \pm Standard Deviation. The statistical significance was evaluated by the analysis of variance (ANOVA) followed by Duncan Multiple Range Test (DMRT) using SPSS ver.18.0. P value less than 0.01 is statistically significant.

\section{RESULTS}

The preliminary phytochemical screening of stem extracts of S.oblonga revealed the presence of potentially bio active secondary metabolites. Among the different solvent extractions aqueous stem extract showed strong positive for the natural constituents such as phenols, flavonoids, tannins, saponins, alkaloids, terpenoids, steroids, cardiac glycosides and coumarins. The results were tabulated in Table I. Thus the aqueous stem extract was used for the quantification of phytochemicals. Flavonoids, terpenoids and tannins were responsible for the anti-diabetic activity. Total flavonoids, tannins and terpenoids were estimated as $19.82 \pm 0.06 \mathrm{mg} \mathrm{QE} / \mathrm{g}$, $96.2 \pm 0.20 \mathrm{mg} / \mathrm{g}, 11.25 \pm 0.03 \mathrm{mg} \mathrm{TAE} / \mathrm{g}$ respectively (Table II).

In vitro anti-diabetic activity was carried out in the aqueous stem extract of $S$. oblonga by using alpha amylase and alpha glucosidase inhibitory assays. S. oblonga showed potential inhibitory effects on these enzymes. Acarbose, a synthetic drug has the ability to inhibit alpha amylase and alpha glucosidase enzymes. Thus acarbose act as a standard for both assays.

Different concentrations $(10,20,40,60,80,100$ $\mathrm{mg} / \mathrm{mL}$ ) of aqueous stem extracts were subjected to alpha amylase inhibitory assay. The maximum percentage of

TABLE I - Qualitative phytochemical analysis of stem extracts of S. oblonga

\begin{tabular}{lccccc}
\hline Phytochemicals & \multicolumn{5}{c}{ Solvent extractions of Salacia oblonga stem } \\
\cline { 2 - 6 } Tested & Aqueous & Ethanol & chloroform & Petroleum ether & Acetone \\
\hline Tannins & + & - & - & - & - \\
Saponins & ++ & ++ & - & + & + \\
Quinones & ++ & ++ & - & - & - \\
Terpenoids & ++ & + & - & + & - \\
Steroids & + & + & + & + & - \\
Flavonoids & ++ & + & + & - & - \\
Phenol & ++ & + & - & - & - \\
Alkaloids & + & - & - & + & - \\
Glycosides & - & - & - & - & - \\
Cardiac glycosides & + & + & - & - & - \\
Coumarins & ++ & - & - & - & - \\
Antho cyanin & - & + & - & - \\
Beta cyanin & + & &
\end{tabular}

+positive; ++ strong positive; -negative 
TABLE II - Quantification of Flavonoids, Tannins and Terpenoids

\begin{tabular}{lcc}
\hline S. No & Phytochemicals & Quantity \\
\hline 1 & Flavonoids (mg QE/g) & $19.82 \pm 0.06$ \\
2 & Tannins (mg TAE/g) & $11.25 \pm 0.03$ \\
3 & Terpenoids (mg/g) & $96.2 \pm 0.20$ \\
\hline
\end{tabular}

$\mathrm{mg} \mathrm{QE} / \mathrm{g}$ - milli gram quercetin equivalent per gram; $\mathrm{mg} \mathrm{TAE} / \mathrm{g}$ milligram tannic acid equivalent per gram;mg/g- milli gram per gram.

inhibition (59.46 $\pm 0.04 \%$ ) was obtained at a concentration of $100 \mathrm{mg} / \mathrm{mL}$, where as the standard drug shown $74.03 \pm 0.03 \%$ at a concentration of $100 \mu \mathrm{g} / \mathrm{mL}$. The $\mathrm{IC}_{50}$ values were calculated for acarbose and stem extract as $64.95 \mu \mathrm{g} / \mathrm{mL}$ and $80.90 \mathrm{mg} / \mathrm{mL}$ respectively. The effective inhibition of alpha glucosidase, tested for the standard and aqueous stem extract of S.oblonga. Different concentrations $(10,20,40,60,80,100 \mathrm{mg} / \mathrm{mL})$ of aqueous stem extracts were subjected to alpha glucosidase inhibitory assay. The maximum percentage of inhibition $(68.51 \pm \mathbf{0 . 0 1} \%)$ was obtained at a concentration of $100 \mathrm{mg} /$ $\mathrm{mL}$ of stem extract. The standard drug acarbose was shown maximum percentage of inhibition $(84.15 \pm 0.03 \%)$ at a concentration of $100 \mu \mathrm{g} / \mathrm{mL}$. The $\mathrm{IC}_{50}$ values were calculated for acarbose $(58.21 \mu \mathrm{g} / \mathrm{mL})$ and stem extract of S.oblonga $(73.56 \mathrm{mg} / \mathrm{mL})$.

From the results it was shown that the aqueous stem extract of $S$. oblonga effectively inhibits the action of both alpha amylase and alpha glucosidase enzyme by a dose dependent manner. The percentage inhibition of alpha amylase enzyme varied from $5.14 \pm 0.04 \%$ to $59.46 \pm 0.04 \%$ at a concentration ranges from 10 to 100 $\mathrm{mg} / \mathrm{mL}$ of stem extract. Like that, the percentage inhibition of alpha glucosidase enzyme varied from $8.92 \pm 0.02 \%$ to $68.51 \pm 0.01 \%$ at a concentration of 10 to $100 \mathrm{mg} / \mathrm{mL}$

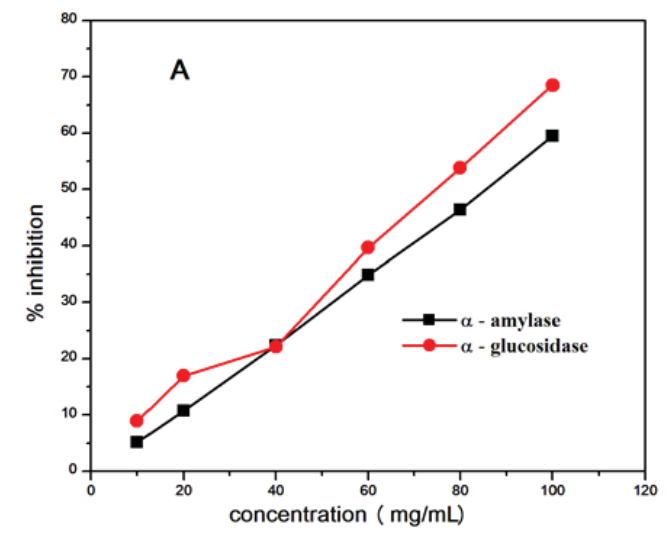

of stem extract of S. oblonga. The percentage inhibition of alpha amylase and alpha glucosidase against various concentrations of acarbose and S. oblonga were compared and graphically represented in Figure 1. It indicates that the stem extract has greater tendency for the inhibition of alpha-glucosidase than alpha-amylase.

Qualitative analysis of chemical compounds might be required for the identification of potential chemical constituents. Gas chromatogram combined with mass spectroscopy is an important tool for such studies. It provides the qualitative information about the chemical constituents and was characterised by mass spectrum. Fifteen therapeutic important compounds were identified from the stem extract of $S$. oblonga through GC-MS analysis (Figure 2). The name of chemical components, molecular weight, molecular formula and their potential activities were shown in Table III.

\section{DISCUSSION}

Diabetes mellitus is a metabolic disorder, a life threatening disease which is increasing day by day. Insulin is key player to regulate carbohydrate, fat and protein metabolism. Insulin deficiency may affect the above important metabolisms. The enzyme alpha amylase and alpha glucosidase may be responsible for the breakdown of carbohydrates into glucose. Alpha amylase is responsible for hydrolysing the starch, which breaks down into glucose before absorption (Abhijit et al., 2014). Inhibition of alpha amylase can lead reduction in post prandial hyperglycemia (Raman et al., 2012). Alpha glucosidase is an enzyme present in the small intestine, used for the cleavage of disaccharides in to glucose. There are many natural constituents available in plants with alpha glucosidase inhibition activity. S. oblonga is considerable example having

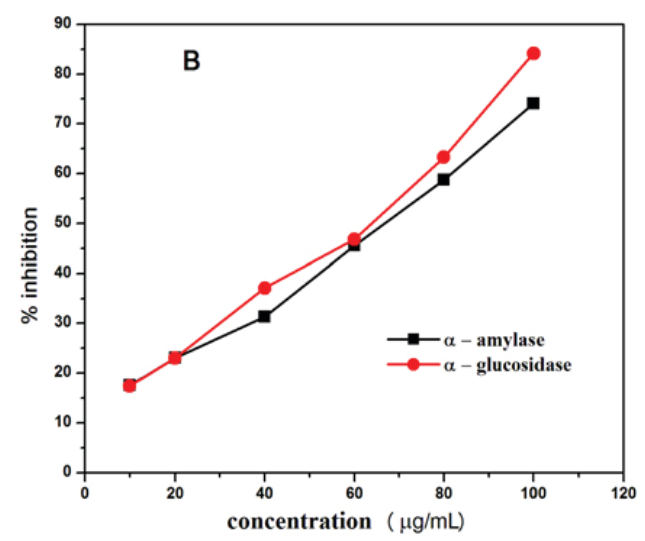

FIGURE 1 - Comparision of $\alpha$-amylase and $\alpha$-glucosidase inhibition. A: $\%$ inhibition of $\alpha$-amylase and $\alpha$-glucosidase against various concentrations of S.oblonga. B: \% inhibition of $\alpha$-amylase and $\alpha$-glucosidase against various concentrations of acarbose 


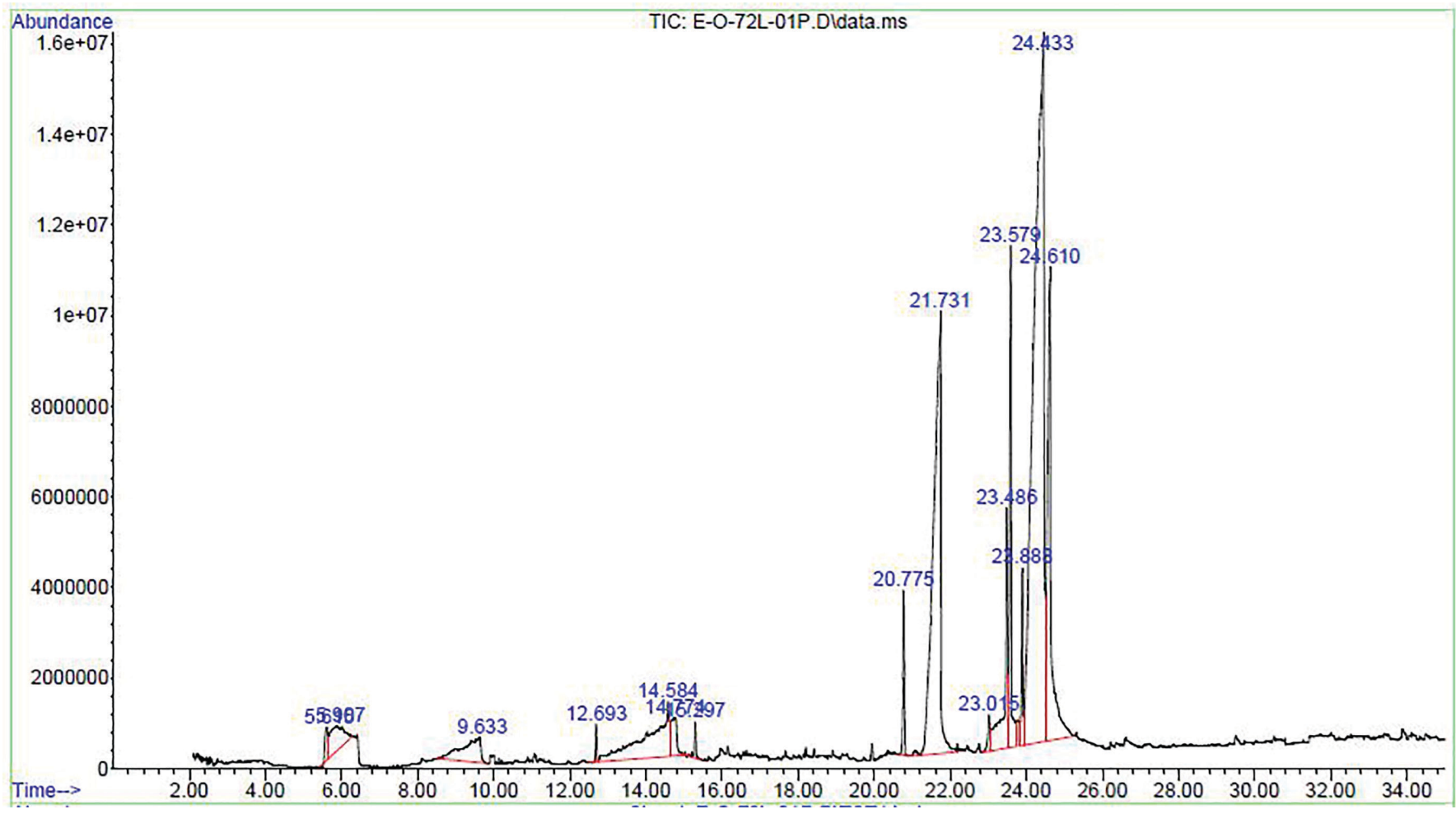

FIGURE 2 - Gas Chromatography Mass Spectrum of stem extract of S.oblonga.

TABLE III - Phytocomponents identified by GC-MS analysis

\begin{tabular}{|c|c|c|c|c|c|}
\hline S. No & RT & Peak area \% & Name of the chemical component & $\begin{array}{c}\text { Molecular } \\
\text { formula }\end{array}$ & $\begin{array}{c}\text { Molecular } \\
\text { weight }\end{array}$ \\
\hline 1 & 5.618 & 0.54 & 1-silacylo-2,4-hexadiene & $\mathrm{C}_{5} \mathrm{H}_{6} \mathrm{Si}$ & 94 \\
\hline 2 & 5.910 & 2.07 & sulfuric acid, dimethyl ester & $\mathrm{C}_{2} \mathrm{H}_{6} \mathrm{O}_{4} \mathrm{~S}$ & 126 \\
\hline 3 & 9.633 & 2.75 & glycerin & $\mathrm{C}_{3} \mathrm{H}_{8} \mathrm{O}_{3}$ & 92 \\
\hline 4 & 12.693 & 0.25 & 3H-pyrazol-3-one, 1,2-dihydro-1,2,5-trimethyl- & $\mathrm{C}_{6} \mathrm{H}_{10} \mathrm{~N}_{2} \mathrm{O}$ & 126 \\
\hline 5 & 14.584 & 6.52 & 1,2,3,4-butanetetrol, [S-( $\left.\left.\mathrm{R}^{*}, \mathrm{R}^{*}\right)\right]-$ & $\mathrm{C}_{4} \mathrm{H}_{10} \mathrm{O}_{4}$ & 122 \\
\hline 6 & 14.776 & 1.29 & $\begin{array}{l}\text { 1,2-ethanediol, 1-(2-phenyl-1,3,2-dioxaborolan- } \\
\text { 4-yl)-, }\left[\mathrm{S}-\left(\mathrm{R}^{*}, \mathrm{R}^{*}\right)\right] \text { - }\end{array}$ & $\mathrm{C}_{10} \mathrm{H}_{13} \mathrm{BO}_{4}$ & 208 \\
\hline 7 & 15.297 & 0.35 & benzene, 1-(1,5-dimethyl-4-hexenyl)-4-methyl- & $\mathrm{C}_{15} \mathrm{H}_{22}$ & 202 \\
\hline 8 & 20.775 & 1.55 & hexadecanoic acid, methyl ester & $\mathrm{C}_{17} \mathrm{H}_{34} \mathrm{O}_{2}$ & 270 \\
\hline 9 & 21.731 & 19.65 & $n$-hexadecanoic acid & $\mathrm{C}_{16} \mathrm{H}_{32} \mathrm{O}_{2}$ & 256 \\
\hline 10 & 23.015 & 0.49 & heptadecanoic acid & $\mathrm{C}_{17} \mathrm{H}_{34} \mathrm{O}_{2}$ & 270 \\
\hline 11 & 23.486 & 4.33 & 10,13-octadecadienoic acid, methyl ester & $\mathrm{C}_{19} \mathrm{H}_{34} \mathrm{O}_{2}$ & 294 \\
\hline \multirow[t]{2}{*}{12} & 23.579 & 5.47 & 9-octadecenoic acid (Z)-, methyl ester, & $\mathrm{C}_{19} \mathrm{H}_{36} \mathrm{O}_{2}$ & 296 \\
\hline & & 5.47 & 9,12-octadecadienoic acid(Z,Z)-, methyl ester & $\mathrm{C}_{19} \mathrm{H}_{36} \mathrm{O}_{2}$ & 296 \\
\hline 13 & 23.888 & 1.64 & methyl stearate & $\mathrm{C}_{19} \mathrm{H}_{38} \mathrm{O}_{2}$ & 298 \\
\hline 14 & 24.433 & 42.09 & 6-octadecenoic acid & $\mathrm{C}_{18} \mathrm{H}_{34} \mathrm{O}_{2}$ & 282 \\
\hline 15 & 24.610 & 11.01 & octadecanoic acid & $\mathrm{C}_{18} \mathrm{H}_{36} \mathrm{O}_{2}$ & 284 \\
\hline
\end{tabular}

RT: Retention Time 
alpha glucosidase inhibitory action. It leads to minimum absorption of mono saccharides. Thus inhibition of alpha glucosidase may be the challenging one to control diabetes (Anuradha Devi, Mallikarjuna, 2016). The methanolic and aqueous extract of Taraxacum officinale showed potential percentage of alpha amylase and alpha glucosidase inhibition (Amin, Sawhney, Jassal, 2015). In our findings, antidiabetic activity of aqueous stem extract of S.oblonga was effective against alpha amylase and alpha glucosidase enzyme. Inhibitory action of stem extracts increases with increased concentration. Similar dose dependent increasing results were obtained on the plants like Syzygium cumini, Psidium guajava (Karthic et al., 2008; Manikandan, Vijaya, Durai, 2013). Most of the herbal plants and its parts have the tendency to reduce the blood glucose level. This is due to the availability of tannins, terpenoids and flavonoids (Osadebe et al., 2010). Tannins and flavonoids have potential inhibitory effects on alpha amylase and alpha glucosidase (Poongunran et al., 2015). The alpha amylase inhibitory action of Tragia involucrate was due to the availability of terpenoids (Vinodhini et al., 2015). In Melia azedarach, the antidiabetic potential was mainly due to the presence of tannins and terpenoids (Khan et al., 2014). Alpha amylase inhibitory effects of tannins were due to its ability to bind carbohydrates and proteins. The above studies proved that, the secondary metabolites like flavonoids, tannins and terpenoids were effectively inhibit alpha amylase and alpha glucosidase. In the present study, the aqueous extract of $S$. oblonga effectively inhibits alpha amylase and alpha glucosidase enzymes with $\mathrm{IC}_{50}$ values 73.56 $\mathrm{mg} / \mathrm{mL}$ and $80.90 \mathrm{mg} / \mathrm{mL}$ respectively. The natural chemical constituents may attribute this activity. In the aqueous stem extract potential amount of flavonoids, tannins and terpenoids were found.

Natural chemical constituents reported by GCMS analysis were shown potential glucose reduction capacity. Various therapeutic compounds were identified through GC-MS by many researchers (Sahaya Sathish, Janakiraman, Johnson, 2012; Gopinath et al., 2013). Such compounds possess antioxidant, antibacterial, antifungal, anti-inflammatory, anti-diabetic and anticancer activities. From the previous studies, it was confirmed that $n$-hexadecanoic acid is an important chemical constituent with antioxidant, hypocholesterolemic, nematicide, pesticide, lubricant, haemolytic 5-alpha reductase inhibitor, anti-inflammatory, antibacterial and antiandrogenic characteristics (Purushoth et al., 2013). 9-octadecenoic acid (Z)-, methyl ester was reported as predominant compound in Gymnema sylvestre (Subashini et al., 2015). GC-MS analysis of methanolic extract of Cassia italica shown the presence of hexadecanoic acid, methyl ester, n-hexadecanoic acid, octadecanoic acid and other constituents with antioxidant, flavour, hypocholesterolemic, pesticide and 5-alpha reductase inhibitor action (Sermakkani, Thangapandian, 2012). 9,12-octadecadienoic acid (Z,Z)-, methyl ester has the property of anti-inflammatory anti-inflammatory, antiarthritic, hepatoprotective, hypocholesterolemic 5-alpha reductase inhibitor, insectifuge and antiarthritic activity (Sudha, Chidambarampillai, Mohan, 2013; Omoregie, Macdonald, Ovuakporie, 2015). Among the fifteen compounds, $n$-hexadecanoic acid, 9,12-octadecadienoic acid(Z,Z)-, methyl ester and octadecanoic acid had potential glucose reduction capacity. This property insists the herbal usage of S. oblonga stem for pharmaceutical purpose. The above studies confirm the anti-diabetic and other bioactive nature of chemical compounds obtained in the aqueous stem extract of $S$. oblonga. The root part of $S$. oblonga also reported for potential antidiabetic activity (Williams et al., 2007). But there is no report on the aqueous stem extract. Thus our study may be helpful for the new drug discovery using the stem part of $S$. oblonga.

From our findings it was concluded that the presence of natural chemical constituents in the aqueous stem extract of $S$. oblonga may be responsible for the effective inhibitory action of alpha amylase and alpha glucosidase enzymes. The inhibitory effect is more towards alpha glucosidase than alpha amylase. This activity supports the herbal usage of aqueous stem extract of $S$. oblonga. Biodiversity plays vital role for the protection of living beings from variety of diseases. Among the plant diversity $S$. oblonga stem extract shown potentially active antidiabetic property. Traditionally the root part of S. oblonga was used for the pharmaceutical purpose, which may destroy the total plant and bring the herb towards an endangered position. Our present study confirmed the alpha-amylase and alpha-glucosidase inhibitory effects of aqueous stem extract of S. oblonga and the GC-MS analysis revealed the presence of active components. Further studies are required for the isolation of antidiabetic compounds.

\section{ACKNOWLEDGEMENT}

The authors are grateful to express their sincere thanks to the chairman and principal of Vel Tech Multitech Dr.RR \& Dr.SR Engineering College and the management of Sathyabama University for their motivation and lab facilities provided to carry out this research work successfully. 


\section{CONFLICT OF INTEREST}

Authors declare no conflict of interest.

\section{REFERENCES}

Abhijit S, Rashmi S, Srivastava, Nikita S, Yashwant M, Bhagyashri C. Anti-diabetic activity of Tridax procumbens. J Sci Innovative Res. 2014;3(2):221-6.

Amin MM, Sawhney SS, Jassal MMS. In vitro antidiabetic studies of various extracts of Taraxacum officinale. Pharm Innov J. 2015;4(1):61-6.

Anuradha Devi V, Mallikarjuna K. In vitro antimicrobial and antidiabetic activity of leaf extracts of Schrebera swietenioides and Homalium zeylanicum. Int J Life Sci Pharma Res. 2016;6(3):1-7.

Arumugam A, Gunasekaran N, Perumal S. In vitro antioxidant, anti-diabetic, cholinestase and tyrosinase inhibitory potential of fresh juice from Citrus hystrix and C. maxima fruits. Food Sci Human Wellness. 2014;3(1):16-25.

Arumugam G, Manjula P, Paari N. A review: antidiabetic medicinal plants used for diabetes mellitus. J Acute Dis. 2013;13(2):196-200.

Babu K, Samundeeswari A, Chitti Babu CV. Studies on phytochemical screening, estimation of tannin and antioxidant activity of Delonix elata Lind. Int J Curr Sci. 2015;15S:E37-42.

Boulekbache-Makhlouf L, Slimani S, Madani K. Antioxidant effects and phytochemical analysis of crude and chromatographic fractions obtained from Eucalyptus globulus bark. African J Biotech. 2012;11(42):10048-55.

Bräunlich M, Slimestad R, Wangensteen H, Brede C, Malterud $\mathrm{KE}$, Barsett H. Extracts, anthocyanins and procyanidins from Aronia melanocarpa as radical scavengers and enzyme inhibitors. Nutrients. 2013;5(3):663-78.

Gopinath S, Sakthidevi G, Muthukumaraswamy S, Mohan VR. GC-MS analysis of bioactive constituents of Hypericum mysorense (Hypericaceae). J Curr Chem Pharm Sci. 2013;3(1):615.

Indumathi C, Durga Devi G, Nithyavani S, Gayathri PK. Estimation of terpenoid content and its antimicrobial property in Enicostemma litorrale. Int J ChemTech Res. 2014;6(9):4264-7.
Ismail TS, Gopalakrishnan S, Begum VH, Elango V. Antiinflammatory activity of Salacia oblonga wall and Azima tetracantha Lam. J Ethanopharmacol. 1997;56(2):145-52.

Karthic K, Kirthiram KS, Sadasivam S, Thayumanavan B. Identification of alpha amylase inhibitors from Syzygium cumini Linn seeds. Indian J Exp Bio. 2008;46(9):667-80.

Khan MF, Rawat AK, Pawar B, Gautam S, Srivastava AK, Negi DS. Bioactivity guided chemical analysis of Melia azedarach L. (Maliaceae), displaying antidiabetic activity. Fitoterapia. 2014;98:98-103.

Mamun-or-Rashid ANM, Hossain MS, Hassan N, Dash BK, Sapon MA, Sen MK A review on medicinal plants with antidiabetic activity. J Pharmacog Phytochem 2014;3(4):149-59.

Manikandan R, Vijaya AA. Durai MG. Phytochemical and in vitro antidiabetic activity of methanolic extract of Psidium guajava leaves. Int J Curr Microbial App Sci. 2013;2(2):15-9.

Matsui TC, Yoshimoto C, Osajima K, Oki T, Osajima Y. In vitro survey of alpha glucosidase inhibitory food components. Biosci Biotech Biochem. 1996;60(12):2019-22.

Mervat MM, Far EL, Hanan A, Taie A. Antioxidant activities, total anthocyanins, phenolics and flavonoids contents of some sweet potato genotypes under stress of different concentrations of sucrose and sorbitol. Australian J Basic Appl Sci. 2009;3(4):3609-16.

Nickavar B, Yousefian N. Inhibitory effects of six Allium species on $\alpha$-amylase enzyme activity. Iran J Pharm Res. 2009;8(1):537.

Nittya KD. Phytochemical analysis and in vitro antioxidant studies of Plumeria obtusa L. leaves. Indian J Pharm Sci. 2016;78(1):169-71.

Omoregie GO, Macdonald I, Ovuakporie UO. GC-MS analysis of the aqueous extracts of Buchholzia coriacea Engl (Capparidaceae), seeds. Int J Life Sci Pharma Res. 2015;5(3):2632.

Osadebe PO, Omeje EO, Uzor PF, David EK, Obiorah DC. Seasonal variation for the antidiabetic activity of Loranthus micranthus methanol extract. Asian Pac J Trop Med. 2010;3(3):196-9. 
Pallavi B, Chandresh V, Kanika K, Tammana T. In vitro evaluation of antidiabetic and antioxidant activity of Seabuckthorn (Hippophae rhamnoides L.). J Med Plants Res. 2015;9(35):929-32.

Poongunran J, Perera HKI, Fernando WIT, Jayasinghe L, Sivakanesan R. $\alpha$-Glucosidase and $\alpha$-amylase inhibitory activities of nine Sri Lankan anti diabetic plants. British J Pharm Res. 2015;7(5):365-74.

Powers AC. Diabetes mellitus. In: Longo DL, Fauci AS, Kasper DL, Hauser SL, Jameson JL, Loscalzo J. Harrison's principles of internal medicine. $18^{\text {th }}$. ed. New York: McGraw Hill Medical; 2011. p.2968-3003.

Priya G, Chellaram C. Evaluation of antibacterial activity and phytochemical analysis of medicinal plant Solanum trilobatum. Int J Pharm Bio Sci. 2014;5(3):354-9.

Purushoth PT, Panneerselvam P, Suresh R, Clement AW, Balasubramanian S. GC-MS analysis of ethanolic extract of Canthium parviflorum lamk leaf. J App Pharm Sci. 2013;3(2):166-8.

Ramamoorthy J, Vanathy, Meera R, Venkataraman S, Devi P. Phytochemical investigation and anti-inflammatory activity of Salacia reticulate. J Chem Pharm Res. 2010;2(5):618-25.

Raman BV, Naga Vamsi Krishna A, Narasimha Rao B, Pardha Saradhi M, Basaveswara Rao MV. Plants with antidiabetic activities and their medicinal values. Int Res J Pharm. 2012;3(3):11-5.

Ranjith S, Rajasree PH, Sankar C. Screening for antidiabetic activity of the ethanolic extract of Barleria cristata seeds. Int J Pharm Life Sci. 2012;3(10):2044-7.

Sahaya Sathish S, Janakiraman N, Johnson M. Phytochemical analysis of Vitex altissima L. using UV-VIS, FTIR and GC-MS. Int J Pharm Sci Drug Res. 2012;4(1):56-62.
Sermakkani M, Thangapandian V. GC-MS analysis of Cassia italica leaf methanolic extract. Asian J Pharm Clin Res. 2012;5(2):90-4.

Sharma L, Sharma A. In vitro antioxidant, anti-inflammatory, and antimicrobial activity of hydro-alcoholic extract of roots of Withania somnifera. J Chem Pharm Res. 2014;6(7):178-82.

Singh SP, Kumar SP In vitro antidiabetic activity of compounds from Pithecellobium dulce fruit peel. Int J Pharm Chem. 2015;5(4):123-7.

Stalin C, Vivekanandan K, Bhavya E. In vitro antidiabetic activity of Cardiospermum halicacabum leaves extracts. Global J Med Res. 2013;13(7):41-3.

Subashini MS, Rajendran P, Ashok G, Kanthesh BM. TLC, FTIR and GCMS analysis of leaves of Gymnema sylvestre R.Br from Kolli Hills, Tamil Nadu, India. Int J Curr Microbiol App Sci. 2015;4(7):757-64.

Sudha T, Chidambarampillai S, Mohan VR. GC-MS analysis of bioactive components of aerial parts of Kirganelia reticulata poir (Euphorbiaceae). J Curr Chem Pharm Sci. 2013;3(2):11322.

Sujata B, Mamta P, Rachana. In vitro antioxidant activity of methanolic-aqueous extract powder (Root and Stem) of Salacia oblonga. Int J Pharm Pharm Sci. 2013;5(3):904-9.

Vinodhini V, Himaja M, Sai S, Poppy D. In vitro antidiabetic activity of Tragia involucrata Linn. Leaf extracts. Int J Res Ayurveda Pharm. 2015;6(1):1-3.

Williams JA, Choe YS, Noss MJ, Baumgartner CJ, Mustad VA. Extract of Salacia oblonga lowers acute glycemia in patients with type 2 diabetes. Am J Clin Nutr. 2007;86(1):124-30.

Received for publication on $19^{\text {th }}$ March 2017 Accepted for publication on $30^{\text {th }}$ August 2017 